\author{
Tolcsvai Nagy Gábor \\ Eötvös Loránd Tudományegyetem \\ Nyitrai Konstantin Filozófus Egyetem \\ tnghu@hotmail.com
}

\title{
ÁTADÁS VAGY KÖZÖS ÉRTELEMKÉPZÉS. KÉT KOMMUNIKÁCIÓS MODELL AZ ISKOLÁBAN ÉS A KULTÚRÁBAN ${ }^{1}$
}

\section{Bevezetés}

A hazai iskolarendszerben nyíltan, a magyar kultúrában inkább rejtve a kommunikáció statikus felfogása uralkodik. Ez a felfogás nem csupán az elvekben, az iskolai tankönyvek szemléletében meghatározó, hanem a gyakorlatban is. A statikusság hirdetője szerint a kommunikáció egyirányú, a beszélő a hallgatónak információt továbbít („átad”), a folyamatban csak a beszélő cselekszik, a hallgató csupán beszélőváltás után lesz aktív, saját megszólalásával. A strukturalizmusból, Jakobsontól származó átviteli modell sajátos módon visszahat a magyar kommunikációs kultúrára, mert annak a dialógust hárító, a nem kérdezést előnyben részesítő, és ekképp az innovációt akadályozó jellemzőjét erősíti. A statikussal szembeállítandó a dinamikus felfogás, amely a beszélőtársak aktív részvételét hangsúlyozza, az időben lezajló közös figyelemirányítást és a közös megértést, melynek során a hallgató is cselekszik, mert mentális erőfeszítést tesz a befogadás érdekében. A beszélő nem átadja az ismeretet (az nála is megmarad), hanem hallgatójának figyelmét arra irányítja, amivel ő is foglalkozik mentálisan, és ebben a közös fókuszálásban, a közös jelentésképzésben kapcsolódik össze két elme, két személy, önreflexíven is. Az előadás a két értelmezéstípus összevetését magyar iskolai tankönyvi példákon mutatja be, kiemelve a statikus felfogás durván leegyszerűsítő és ekképp káros voltát, valamint hangsúlyozva a dinamikus felfogás segitő jelentőségét az oktatásban és általában a kultúrában, többek között Tomasello (2002) és Luhmann (2006) munkáira hivatkozva.

\section{A statikus strukturalista kommunikációs modell}

Előadásomban a magyar kultúrában évtizedek óta uralkodó kommunikációs modell káros következményeiből kiindulva olyan kommunikációértelmezést vázolok, amely nem csupán

1 A tanulmány az NKFIH által támogatott $A$ magyar nyelv igei konstrukciói. Használatalapú konstrukciós nyelvtani kutatás (129040) pályázat keretében készült. 
a közoktatásra lehet jótékony hatással, hanem a magyar kommunikációs kultúrára is. Jelezni kell, hogy a kommunikáció dinamikus, használati alapú értelmezése és ezzel együtt a strukturalista felfogás hárítása nem elözmény nélküli a hazai általános kommunikációelméleti szakirodalomban, vö. például Terestyéni (2006). A jelen dolgozat a kognitív nyelvészet használatalapú keretében tárgyalja a kérdést (vö. Kemmer-Barlow 2000).

Kiinduló állításom a következő:

- az általánosan elterjedt Jakobson-féle strukturalista modell (vö. Jakobson 1969) statikus és passzivitásra késztet;

- a funkcionális triadikus modell (vö. Tomasello 2002; Tátrai 2011) ezzel szemben a beszélőtársak közös cselekvését és megértését feltételezi, a kommunikációt dinamikus közösségi tevékenységnek tekinti.

A strukturalista modell egyik legfőbb hátránya a kérdezés háttérbe szorítása, a beszélgetés nyitottságának sugallt elutasítása. A magyar kultúra nem kérdező kultúra: a kérdezés, a kérdésekre alapuló kommunikáció alig része a gyakorlatnak. Ez posztkoloniális jelenség, a kommunista diktatúra maradványa, de feltűnően erős a megléte. Ennek egyik oka az évtizedek óta hirdetett, tanított, a közoktatásban és a kézikönyvekben, közmüvelődési enciklopédiákban sulykolt Jakobson-modell, eredeti változatában 1958-ból (Jakobson 1969). A modell késői uralma a magyar nyelvközösség és a magyar kultúra posztkoloniális helyzetéből, annak meg nem haladásából ered (l. Tolcsvai Nagy 2016). A kérdezés háttérbe szorítása a világ aktív és innovatív megismerése helyett a felülről jövő, megmondó tanítást és a passzív tanulást helyezi előtérbe.

A funkcionális triadikus modell abból a valós helyzetből indul ki, amelyben két ember beszélget egy percepciós térben, ahogy ezt ősidők óta teszik az emberek, minden további közvetítőközeg igénybevétele nélkül. A jelen tanulmányban (és az ennek alapjául szolgáló konferencia-előadásban) mondandóm, vizsgálatom a közoktatásra és a ma használatos magyar nyelvtankönyvekre korlátozódik.

\subsection{A Jakobson-modell}

Jakobson kommunikációs modellje a metaforáival jellemezhető a legpontosabban. Az alábbi rövid bemutatás a modell magyar kulturális környezetben megvalósult, a magyar tankönyvekben és kézikönyvekben évtizedek óta egyeduralkodó leírásként ismert változatra összpontosít. A magyar fordításban a feladó (vagy adó) és a cimzett (vagy vevő) kifejezések elsőként egyfajta POsTA metaforát hoznak működésbe: a feladó postára teszi üzenetét, a címzett kézhez veszi, a feladótól elkülönülve, kibontja és megérti. Mindez a csatorna közvetítésével történik, ami viszont a rádió és televízió mediális szerkezetét idézi fel. Jakobson modellje végső soron a kibernetika korszakának terméke, annak a korszaknak, amely az első működő számítógépek megjelenésével hirtelen mindent a gépi működés információtovábbítási folyamataihoz kezdett mérni. Itt tehát 
az emberi kommunikáció leírásának alapja a gépi kommunikáció szerkezete: a termosztát két eltérő fémből készült lemeze hőhatás (növekvő vagy csökkenő hőmérséklet hatása) eredményeként összeér, ez áramkört zár, és bekapcsol vagy kikapcsol a kazán. A feladótól a címzetthez jut az üzenet. Ilyennek látszik a rádió- és televízióadás is, és innen lehet visszajutni a leképezésben két ember beszélgetéséhez. A Jakobson-féle kommunikációs modell statikus, mert elkülöníti a két beszélőtársat egymástól, nem vesz tudomást a kommunikáció időben történő jellegéről. Ez a modell alapvetően egyirányú, mert csak a beszélőt tekinti aktívnak, a hallgatót passzívként állítja, ennek kommunikációs cselekvését csak a válaszban tételezi.

\subsection{A Jakobson-modell a tankönyvekben}

Tanulságos a kommunikációs ismeretek bevezetése, magyarázata és ábrázolása a 2010-es években érvényes magyar nyelvtankönyvekben. Elsőként érdemes szóba hozni a kommunikáció és a nyelvi rendszer összekapcsolásának módját. E tekintetben a legkülönösebb eljárást az OFI (Oktatáskutató és Fejlesztő Intézet) 9. évfolyamos tankönyvében lehet megtalálni: a tankönyv szerzői a kommunikáció, illetve a hangtan, alaktan témaköröket kis, kétoldalas egységekre bontva felváltva tárgyalják. Ez a szerkesztésmód egymással össze nem függő kis tematikus egységeket váltogat anélkül, hogy bármi kapcsolat lenne nyilvánvalóvá a diákok számára. A tankönyv tartalomjegyzékének első része ezt a szervetlen vegyülékességet pontosan bemutatja (Hegedűs-Téglásy 2014: 7):

A beszéd és a nyelv 12 .

Mi a kommunikáció? 14 .

A magánhangzók 16.

A kommunikáció tényezői 18.

A mássalhangzók 20.

A kommunikáció funkciói 22.

A szóelemek 24.

Új szóbeliség: skype, chat 26.

A toldalékmorfémák 28.

Internetetikett 30 .

A szóalkotás módjai: szóösszetétel, szóképzés 32.

Írott-beszélt átmenetiség 34.

Ritkább szóalkotási módok 36.

Internethitelesség 38.

A tankönyv indoklást ad ehhez az eljáráshoz: „Eddig, az 5-8. osztályban elsősorban a nyelvi rendszer leírásáról tanultál. Ennek ismétlésével kezdődik ez a könyv, hiszen nagyon fontos, hogy meg tudd formálni gondolataid. Mindig látnod kell azonban, hogy ez csak eszköz, a cél ennél sokkal bonyolultabb. Ezért ebben a könyvben 
a nyelvi jelek és szabályok leírásával párhuzamosan megjelenik a gyakorlati alkalmazás, a kommunikációs helyzetek megoldása, a szövegalkotás, a szövegértelmezés, azaz a jelentés megteremtése" (Hegedűs-Téglásy 2014: 5). Ez a szerkesztési és tárgyalási mód látszólag a rendszer és a használat szoros összefüggését sugallja, eredménye azonban azzal éppen ellentétes. Ugyanis a tematikus alegységek egymástól elszakított jellege valójában gépiessé teszik a kommunikációt a tanuló számára. Hiszen aligha fedezhető fel közvetlen kapcsolat például a toldalékmorfémák és az internetetikett között, jóllehet a könyvben egymásra következnek. $S$ bár a jelen tanulmány más vonatkozásokkal nem foglalkozik, megjegyzendő, hogy a kommunikáció tárgyalásában lényegében minden típus és példa az elektronikus kommunikációra korlátozódik, tovább csökkentve a természetes szóbeli és írásbeli nyelvi tevékenységek ismeretét, és tovább növelve ezek tekintélycsökkenését.

Az Antalné Szabó Ágnes és Raátz Judit szerzőpáros által készített tankönyvcsalád 9-10. évfolyamos tankönyve egyrészt azonosul az eredeti Jakobson-féle modellel, másrészt kissé árnyalja azt pragmatikai szempontokkal. Definíciójuk szerint „A kommunikáció [...] tájékoztatást, információk cseréjét, közlését jelenti” (Antalné-Raátz 2001: 16). A meghatározás - amely általános, közismert a magyar kultúrában - leszúkíti az ember nyelvi tevékenységét az információközlésre (tehát valamilyen „új” ismeret megfogalmazására), miközben más funkciókat nem is említ, jóllehet az eredeti modell is tartalmaz ilyeneket, illetve a tankönyvben két oldallal később éppen a különböző funkciókról esik szó.

A szerzők megtartják a Jakobson-értelmezés statikus jellegét: „Fontos tényezők a résztvevők, azaz a feladó és a címzett. A feladó az, aki különböző jelek (nyelvi és nem nyelvi jelek) segítségével üzenetet küld a címzettnek. A címzett ezt az üzenetet felfogja, értelmezi, ha módja van rá, akkor válaszol. Ez utóbbi esetben a résztvevők szerepet cserélnek, és a címzett válik feladóvá” (Antalné-Raátz 2001: 17). A beszélőtársak elkülönülése itt is egyértelmü, semmi nem utal a közös nyelvi tevékenységre. A címzett eszerint csak akkor cselekszik, ha módja van a válaszadásra.

A beszélőtársak fenti módon értelmezett szerepe a kommunikáció folyamatának rövid tipizálásában is megmutatkozik: „Egyirányú a kommunikáció akkor, ha a folyamaton belül a hallgató nem töltheti be a beszélő (a feladó) szerepét. [...] Kétirányú a kommunikáció akkor, ha a beszélo" és a hallgató állandóan szerepet cserél" (AntalnéRaátz 2001: 18). A tankönyv az egyirányú kommunikációra példaként az iskolai előadást, a televízióadást, a kétoldali kommunikációra a beszélgetést és a telefonálást nevezi meg. Itt mutatkozik meg ennek a modellnek az egyik legkomolyabb korlátja, hiszen az a mindenkori hallgatót passzivitásra kárhoztatja. Mint lejjebb szó lesz róla a triadikus kommunikációs modell kapcsán, a hallgató nem pusztán hallgat, hanem mentális erőfeszítéseket tesz a beszélő szövegének a megértéséért. Ezáltal a kommunikáció során a beszélőtársak egymás felé és témájuk felé irányulnak. A nyelvpedagógiai felhasználású modell káros hatása ezért tágabb, mert a fenti idézet szerint a diákot is passzív hallgatónak tekinti, holott aktív megértőnek, a beszélő, előadó tanárral együtt 
mentálisan tevékenykedő résztvevőnek kellene konceptualizálni és a tanári gyakorlatban ezt a szemléletet érvényesíteni a jobb tanulási eredmények érdekében.

A nyelv értelmezése szintén a Jakobson által bevezetett kibernetikai fogalmi tartomány keretében történik meg: „Az üzenetet kifejező összefüggő jeleket kódnak nevezzük. [...] A kommunikáció csak akkor lesz hatékony és sikeres, ha a felhasznált kódot a résztvevők egyformán ismerik, azaz közös nyelvet beszélnek. [...] A közösnyelvűség tehát a kommunikációs partnerek azonos gondolkodásmódját, azonos szóhasználatát, nyelvi stílusát, nyelvi magatartását, nyelvi illemét is jelenti” (Antalné-Raátz 2001: 17). $\mathrm{Az}$ idézett részlet több jelentékeny kérdést is tisztázatlanul hagy a tanulók számára. Nem egyértelműsödik a kód és a nyelv viszonya. Kérdéses a közösnyelvűség több kritériuma: ha a kommunikáció feltétele „azonos gondolkodásmód, azonos szóhasználat, nyelvi stílus, nyelvi magatartás", akkor igen kevés nyelvi tevékenység lenne sikeres. Az emberi kommunikáció természetesen igen gyakran eltérő gondolkodásmódú, stílusú és viselkedésű beszélők között történik meg. A tankönyv és a mögöttes nyelvpedagógiai hagyomány rejtett homogenizálási szándéka az emberi dialógus egyik alaptényezőjét kívánja kiiktatni, azt, hogy eltérő személyiségek egymástól elkülönülő mentális világa kapcsolódik össze minden beszélgetésben. Emellett olyan nyelvi, mentális és kommunikációs eszményt sugall ez a felfogás a diákoknak és a tanároknak, amely túlzó elvárásokat támaszt, és kommunikációs zavarokhoz vezethet.

Mivel a Jakobson-modell fontos összetevője a referenciális funkció (a jelentés és a vonatkozás együttesen), ezért az Antalné-Raátz tankönyv erre is kitér ekképp: „A hatékony kommunikációnak fontos feltétele a közös valóság és a közös előismeret. A közös valóság azt a valóságdarabot jelenti, amelyet mind a két félnek ismernie kell a világból ahhoz, hogy kommunikálni tudjanak. Ha ez hiányzik, akkor azt a megfelelő információk, ismeretek átadásával kell pótolni. A sikeres kommunikáció további feltétele, hogy a kommunikációs partnereknek megfelelö ismereteik, megfelelő tudásuk legyen arról, amiről beszélgetnek" (Antalné-Raátz 2001: 17). Itt ismét olyan idealizációval találkozik a diák és a tanár, amely ellentmondásban van a modell más részeivel, és igen ritkán valósul meg. A kommunikációs tevékenységben általában vannak olyan aktivált ismeretek, amelyek mindkét beszélőtárs számára hozzáférhetők, „tudják” azokat. Azonban az egyezés mértéke mindenképpen fokozat kérdése: egy beszélő mesélhet egy olyan témáról, amelyről a másik fél lényegében semmit nem tud felső tagozatos általános ismereteken túl, amelyeket már csak részlegesen és esetleg átkonstruálva tud alapként felidézni, így a neki mondottak legnagyobb része újdonság a világról való ismeretei sorában. Ugyanez a helyzet egy müszaki (például egy számítógépes elektronikai) újítás eredményének a megismerésekor. Amennyiben a kommunikáció ismeretátadás (erről lásd még alább), akkor ennek alapesetben akkor van értelme, ha az egyik fél tud valamit, amit a másik nem. Ekkor vagy az egyik fél közölni szeretne valamit, vagy a másik fél meg akar tudni valamit. És éppen az iskola az a hely, ahol az egyik kommunikáló fél, a tanár birtokában van olyan ismereteknek, 
amelyek még nem állnak a diákok rendelkezésére, és mégis itt van igazán szüksége kommunikációra. Az ekképp idealizált általános tudás mint a kommunikáció feltétele ismét rejtetten túlzó elvárást állít a diákok és a tanárok elé.

A fentiekkel együtt, bár összehangolatlanul jelennek meg az Antalné-Raátztankönyvben funkcionális szempontok is, például a jelentés helyzethez igazításáról: „A szöveg, a közlemény (akár beszélt, akár írott) mindig egy adott beszédhelyzetben hangzik el. Így a kommunikációnak mindig ott és akkor, az adott helyzetben van jelentése. Ebben a jelentésben benne foglaltatik a helyzet külső és belső körülménye, a partnerek viselkedése, a köztük lévő kapcsolat (kontaktus), a nyelvi és a nem nyelvi jelek" (Antalné-Raátz 2001: 17). E dinamikus jelentésértelmezés igen fontos, bár kétségkívül pontosításra szorul, ugyanis általában a konvencionális érvényü lexikális és grammatikai jelentések szöveghez és kontextushoz igazítása történik meg a nyelvi tevékenységben. Ez a tényező azonban nehezen fér össze a nyelv (a „kód”) használati feltételeit általánosságban hárító modellel.

Az OFI tankönyvei az előzőekben jellemzett tankönyvcsaládhoz hasonlóan mutatják be a kommunikációt. A 5. évfolyamos tankönyv 52. oldalán a színes ábrán a feladó és a címzett között a csatorna közvetít (két irányban nyilazva), mellyel párhuzamban a zaj kétirányú nyilai láthatók. A feladó és a címzett között látható az üzenet, masnival becsomagolt dobozban. Ez a gyerekeknek bizonnyal kedveskedő, szemléletesnek szánt ábrázolási mód a legárulkodóbb, hiszen azt jelzi, hogy az üzenet valamiféle fizikai tárgy lenne, ami egy dobozba csomagolva mindenfelé vihetö, anélkül, hogy lényege változna. Vagyis az üzenet itt is el van választva a beszélőtársaktól, azoktól független a létezésmódja. Lényege a továbbíthatóság, az egyik kézből a másikba adhatóság (a postametaforának megfelelően), de maga a kommunikáció eltűnik, mert nincsen szó az egymásra és a beszéd tárgyára figyelésről, a közös nyelvi tevékenységről, a megértésért tett erőfeszítésekről. Ezt a hiányt valamennyire ugyan enyhíti a megelőző egyik szövegrész, de az ábra domináns hatása kétségtelen.

Az OFI 9. évfolyamos könyve a „közlésfolyamatot” ekképp foglalja össze: „A kommunikáció, latin eredetủ szavunk a 'közzététel, teljesítés, megadás; a gondolat közlése a hallgatóval' jelentésű communicatio fönévből származik. A kommunikáció eszerint tájékoztatást, információcserét jelent. A kommunikáció létrejöttéhez valamilyen eszközre, jelrendszerre van szükség. Az egyik legelterjedtebb jelrendszer a nyelv, de kommunikáció jöhet létre állat és ember, ember és gép, sőt gép és gép között is, tehát nem csak verbális, szavakon alapuló kommunikációs formák vannak. A kommunikáció általában kétirányú (kivéve ha az egyik félnek nincs módja visszajelzésre)" (Hegedűs-Téglásy 2014: 14). A meghatározásban a kommunikációt ez a tankönyv is egyetlen funkcióra, az információcserére korlátozza. E korlátot a könyv csak néhány oldallal később oldja, szigorúan a Jakobson-féle funkciók felsorolásával (a 22. oldalon, mondatfajtákkal összefüggésbe hozva). A kétirányúság itt is a címzett válaszadási lehetőségében valósulhat meg, a közös figyelmi és referálási műveletek 
nem férnek a modellbe. Hiszen magát a kommunikációs tevékenységet egyirányúnak mutatja be: „A kommunikációs folyamatban az adótól (feladótól) indul az információ, az üzenet, amely a vevőhöz (címzetthez) valamilyen csatornán keresztül jut el” (Hegedűs-Téglásy 2014: 18). Jóllehet a szöveg említi a másikra irányuló figyelmet, de ez a feladó és a címzett egymástól elkülönült tevékenységében nyilvánul meg. A beszélő és a hallgató szerepe mintegy kimerevedik, kimondatlanul is állandósul, miképp az eredeti Jakobson-féle leírásban. Ezt a merevséget a kontextus és a résztvevők közötti kifejtetlen kapcsolat említése nem enyhíti. Ezért az OFI tankönyvében is kissé szervetlenül jelenik meg az a pragmatikai szempont, amely a konvencionális jelentés és a kontextus közötti viszonyt emeli ki: „Az üzenet mindig egy adott beszédhelyzetben hangzik el. Így a kommunikációnak mindig csak az adott helyzetben van jelentése, az elhangzó információt mindig ott és akkor kell értelmezni. Ebből következik, hogy ugyanannak a mondatnak különböző beszédhelyzetekben akár gyökeresen eltérő jelentése is lehet" (Hegedűs-Téglásy 2014: 18). Az ellentmondásosság abból ered, hogy a szövegrész felfüggeszti a tankönyvben uralkodó rendszerszemléletből eredő stabilitást, vagyis a rendszerelemek (lexikai és grammatikai elemek) jelentésének konvencionális jellegét, valamint nem adja meg a beszédhelyzetnek azokat a tényezőit, amelyek a jelentés kontextushoz igazítását irányítják.

A tankönyv szövege egyrészt rendszeresen az elektronikus kommunikáció formáit említi, azokat helyezi előtérbe mint a nyelvi tevékenység legfontosabb formáit, miközben fontosnak minősíti a tekintettartást, a szemkontaktust, amely természetes formájában csakis a közvetlen, egy percepciós térben zajló beszélgetés során lehetséges. Túlzottan egyoldalúnak tűnik a tankönyv felsorolása, erősen rájátszva a világhálótól és a közösségi felületektől való függésre: „A 21. században rengeteg módon kommunikálunk: a facebook, a twitter, az SMS, a telefon, a beszélgetés a haverokkal, az órai felelés mind-mind magától értetődően a kommunikáció része. Talán kevésbé egyértelmű az, hogy az integetés, a kutya ugatása, a bólogatás, a szemráncolás, a madarak csiripelése és még sok más egyéb is ugyanígy kommunikáció - tehát nem kötődik feltétlenül az emberi nyelvhez" (Hegedűs-Téglásy 2014: 14). A mindennapi beszédhelyzetek hagyományos és gyakori típusai (család, vásárlás, közlekedés, hivatal, iskola, templom, baráti társaság) alig kapnak említést.

\section{A funkcionális triadikus modell}

A kommunikáció lényegét emberi nézőpontból sokszor megfogalmazták már. Ez a perspektíva az egyedülálló humán lényeget ragadja meg, távol minden gépi működéstől. E megközelítésekből Terestyéni Tamás tömör összefoglalását érdemes itt felidézni (Terestyéni 2006: 14): „a kommunikáció az emberek közötti együttműködés, a kölcsönös megértés, az egymásra találás, a megegyezés terméke. Legmélyebb alapjaiban maga is együttműködés, és egyúttal minden más természetű együttműködés elengedhetetlen tartozéka, kovácsa, elősegítője”. 
A Terestyéni-féle leírást a triadikus kommunikációs modellel lehet részletezni, kibontani. Ennek elvégzéséhez azonban szükséges a Jakobson-féle modell további általános jellemzőinek a bírálata.

Mint látható volt, a strukturalista kommunikációértelmezés statikus, egyirányú, amelyben a hallgató passzív, amíg nem kap szót. Ez a modell arra a sztereotip karikatúrára emlékeztet, amelyben az egyszeri tanuló az iskolapadban ül, a fejébe tölcsér van illesztve, s azon keresztül önti be a tudást a tanító néni. A gyerek tehát illedelmesen ül a padban, és várja a kész tudást. Ebben a felfogásban a diák, általában a beszélgetésben pillanatnyilag hallgató le van választva a nyelvről és valójában az élő emberi kommunikációról.

A strukturalista Jakobson-modell evidensnek tartja, hogy tudni lehet, mi van a másik fejében. Mintha egy külső szemlélő közvetlenül belelátna a beszélőtársak elméjébe, és azt tapasztalná, hogy a beszélőtársak is pontosan tudják, mit tud a partnerük, és éppen mire irányítja a figyelmét. Holott ez így nem lehetséges, mert egyrészt eltérő világ- és nyelvi ismeretek, eltérő szándékok, beállítódások, viselkedések jellemzik a beszélőket, másrészt csak részben ismerik vagy ismerik föl a társ tudását és beállítódását, célját (vö. Luhmann 2006: 275). Ami mégis lehetővé teszi a kommunikációt, az az értelem. Az értelem általános közegében történik eleve minden nyelvi tevékenység, a beszélő eleve azt feltételezik, hogy az értelem adja a kommunikáció közegét (Luhmann 2006: 207-232). „[A]z értelem az a médium, ami az aktualitás és a potencialitás különbségével dolgozik, mégpedig differenciával, megkülönböztetéssel abban az értelemben, hogy a megkülönböztetés egysége mindig részt vesz a játékban, tehát hogy abban, amit aktuálisan látunk, mindig lehetőségperspektívák vannak, és fordítva, a lehetőségeket nem tematizálhatjuk" (Luhmann 2006: 220).

A tankönyvek a kommunikáció fó funkciójaként az információ átadása vagy cseréje cselekedetét nevezik meg. Azonban látni kell, hogy a kommunikáció során nem cserélünk, nem adunk oda semmit, a tudás a beszélőnél is megmarad (Luhmann 2006: 274). Sokkal inkább a tudás megsokszorozódásáról van szó, annak kiterjesztéséről, felhalmozásáról (vö. még Tomasello 2002). Az adott helyzettől elválasztható tapasztalat általánosítása jellegzetesen emberi tulajdonság, amely lehetővé teszi a kulturális kumulációt. Ennek az örök folyamatnak nyilvánvalóan része a felejtés, valamint a szelekció, amellyel bizonyos (többnyire releváns) információk maradnak meg.

Mindezek mellett a kommunikáció téri-idő kontinuumban történik, a közlés és a megértés egyidejüsége általános jellemző, miközben a kommunikáció rá van utalva az egymásutániságra. Nincs információ közlés és megértés nélkül, továbbá az információ mindig valamilyen szelekciós horizontban, azaz felidézett (létrehozott, nem előre adott) kontextusban jelenik meg.

Az emberi kommunikációról meglévő ismereteket a legárnyaltabban a triadikus modell (1. ábra) foglalja össze. 


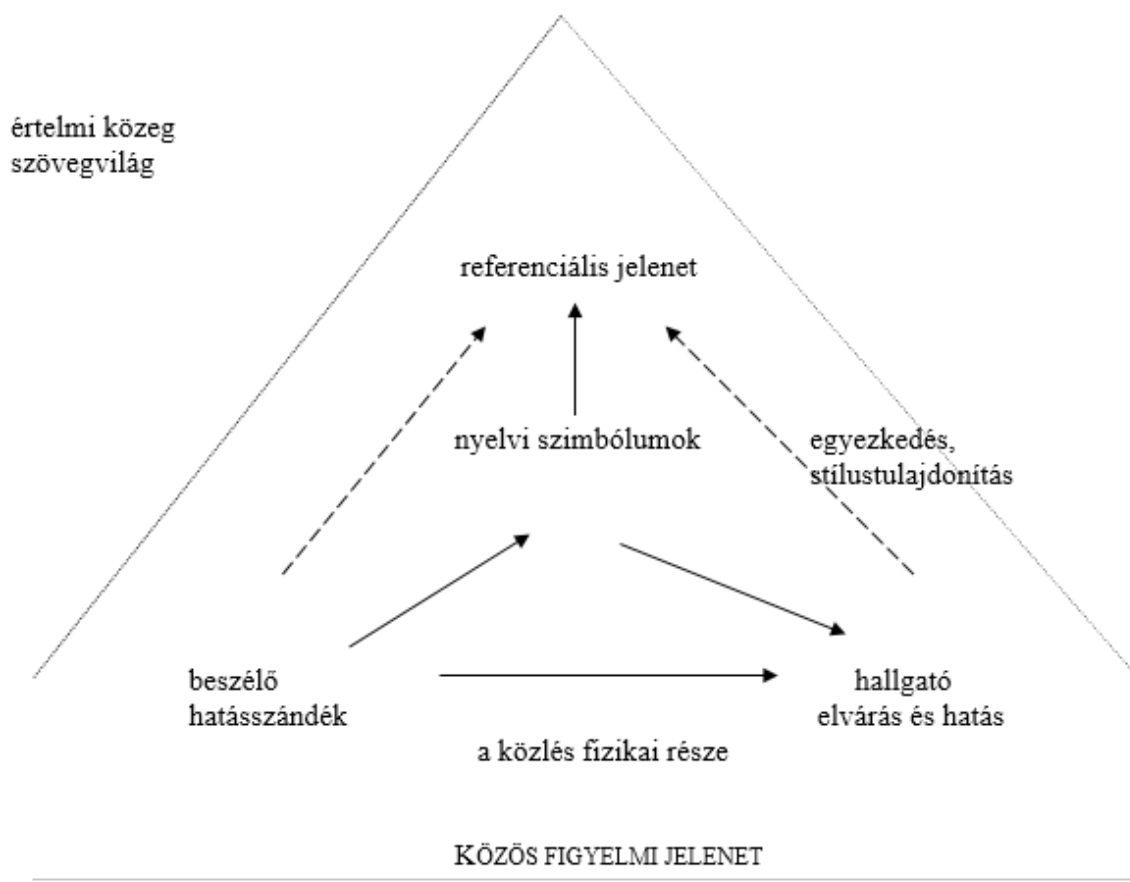

1. ábra: A kommunikáció alapsémája, az időben történő kommunikáció egy adott szakaszában, egy referenciális jelenetre (tipikusan egy elemi mondatra) érvényesen, Tomasello (2002) és Tátrai (2011) alapján

A prototipikus kommunikációs során két ember beszélget egy percepciós térben, azaz közvetlenül, áttétel nélkül érzékelik (elsősorban hallják) egymást.

A nyelvi kommunikációval minden ember legalapvetőbb célja az, hogy társas tevékenység során jelentéseket állítson elő és ezeket a jelentéseket hozzáférhetővé tegye mások számára. A nyelvi kommunikáció szövegben valósul meg, az ember szövegben beszél, valamilyen módon. A nyelvi tevékenységben a jelentések előállítása társas tevékenység, a nyelvi interakciókban a mindenkori beszélő és a hallgató közösen hozzák létre a megértés tárgyát, az éppen beszélő kezdeményezésére, de közösen irányítják figyelmüket a beszélgetés tárgyára. A beszélgetés tárgyát a nyelvi kifejezések szövegbeli elrendezésben, egyszerre funkcionális (szemantikai) és alaki (grammatikai) szerkezetekben fejtik ki, hatást kiváltva. Az emberi megszólalás során:

- a mindenkori beszélő a pillanatnyi hallgatót szólítja meg,

- a beszélőnek szándéka, célja van,

- a beszélő valamilyen tartalmat kíván a másik számára hozzáférhetővé tenni, 
- a beszélő a beszélőtársak figyelmét egy közös harmadikra, a beszélgetés tárgyára irányítja,

- a beszélgetés tárgyát és annak nyelvi kifejezését a beszélőtársak közösen értik meg,

- a nyelvi tevékenység valamilyen közösségi nyelvi formában és az értelem emberi közegében történik.

A nyelvi kommunikáció emberek között történik, a beszélőtársak szándékaival, elvárásaival és megértési folyamataival együtt, mindig valamilyen beszédhelyzetben (vö. Sinha 2009; Tomasello 2002; Tátrai 2011, 2017). A prototipikus beszédhelyzetben két ember beszélget egy percepciós térben (egy tér- és időkontinuumban), vagyis a beszélőtársak közvetlenül érzékelik egymást, közel vannak egymáshoz. Ebben a nyelvi interakcióban közösen cselekszenek: a beszélő beszél, a hallgató pedig feldolgozza a beszélő szövegét. Mindkét beszélőtárs cselekszik, aktív, hiszen mind a beszéd, mind a beszéd megértése tevékeny embert kíván. Ezzel együtt a pillanatnyi beszélő és hallgató viszonya aszimmetrikus, mert a beszélő irányítja a hallgató figyelmét. Minden beszélőtárs mindig integrált beszélö/hallgató, vagyis a beszélgetés egyik szakaszában beszélö, a másik szakaszban hallgató, és a két szerepet tudja váltogatni. Emellett a pillanatnyi beszélö mindig hallja saját beszédét, a pillanatnyi hallgató pedig belső, mentális választ tervez vagy hoz létre társa beszéde alatt, amelynek egy részét gyakran el is mondja, amikor rá kerül a sor.

A kommunikáció többrétegű folyamat. Egyrészt a beszélőtől egyirányú fizikai folyamatként eljut a szöveg fizikai teste a hallgatóhoz: a beszélő hangokat ad ki, amelyek hullámként terjednek, és észlelhetők a hallgató számára. Illetve a beszélő írásban rögzíti szövegét, amelyet a hallgató vizuálisan tud észlelni. A nem hangzó nyelven, a jelnyelven kommunikáló beszélőtársak jelelnek, vizuálisan feldolgozható jeleket alkalmaznak.

Másrészt a beszélőtársak közösen egy harmadikra, beszélgetésük tárgyára, annak szövegszerủ megjelenítésére és körülményeire irányítják a figyelmüket. A kommunikáció során a beszélő nyelvi tevékenysége egyrészt a hallgatóra irányul, a hallgató pillanatnyi mentális, figyelmi állapotát változtatja meg közlésével. E tevékenység a közös figyelmi jelenetben valósul meg, abban a folyamatban, amelyben a beszélötársak ugyanarra a harmadikra irányítják figyelmüket, és ezt tudják egymásról. Ebben a folyamatban a beszélö a kezdeményező, a saját figyelmét valamely jelenség köti le, és beszédével társának a figyelmét is arra irányítja. A beszélő nyelvi cselekvése másrészt a beszéd tárgyára, tehát a szövegben megjelenített tartalomra mint referenciális jelenetre irányul, a beszélőtársak közösen ugyanazokra a dolgokra, folyamatokra, jelenetekre vonatkoztatják a szöveg egyes elemeit, ezekre referálnak. A referenciális jelenet az az időben lezajló esemény, amelyet például egy mondat a beszélők számára kifejez.

Az emberi kommunikáció mindig időben történik, a nyelvi tevékenységnek (két ember beszélgetésének) időbeli lefolyása van. Ebben a kommunikációs folyamatban érvényesül a pillanatnyi beszélő hatásszándéka (az a hatás, amit a hallgatójából kiváltani kíván). 
Ez a hatás nem merül ki a tartalmi elemek közlésében, hanem a hatáshoz hozzájárul a beszélő viselkedése, a beszédhelyzet jellegének alakulása.

A kommunikációs folyamatban szintén érvényesül a pillanatnyi hallgató elvárása, amely a beszélő nyelvi tevékenységére vonatkozik (a hallgatónak vannak elvárásai a beszélő stílusával, a hallgatóhoz és a témához való viszonyának nyelvi megjelenítésével kapcsolatban). A hatásszándék és az elvárás egyezkedési műveletekben találkozik össze a két beszélőtárs nyelvi tevékenységében.

A nyelvi tevékenység interszubjektív: a beszélőtársak (a pillanatnyi beszélő és hallgató) együtt hozzák létre a kommunikációs folyamatot és azon belül a megértést. Amíg a hallgató másként nem jelez, a beszélő szövegét, nyelvi szerkezeteit úgy érti (többnyire, nagyjából), ahogy azt a beszélő érti és értetni szándékozza. Az emberi kommunikáció együttműködő természetű, a beszélőtársak közös figyelemirányítása és közös megértése (jelentésképzése) evolúciós eredetű: a perspektívamegosztás, a közös nézőpont (megismerési keret) nélkülözhetetlen a közösség fennmaradásához (például a reprodukció, vadászat, védelem vagy kényelem területén). Ez a biológiai adaptációs folyamat eredményezte a kultúra kialakulását, majd annak ma is működő kumulációs (tudásfelhalmozó) folyamatait, amelynek előfeltétele és közege az együttmüködésen alapuló kommunikáció (vö. Givón 2002; Tomasello 2002). És ebben a folyamatban alakultak ki és működnek az együttműködés kommunikációs változatai: az informálás, a kívánság (parancs), az elbeszélés.

A prototipikus emberi kommunikáció közös cselekvés két vagy több beszélőtárs között, akik figyelmük közös irányításával, a megkonstruált nyelvi kifejezések közös megértésével tartanak fönn kapcsolatot egymás között. A kommunikáció tehát mindig információ (az, amiről szó van, a referenciális jelenetek sora), kommunikáció és megértés egysége, úgy, hogy e három tényező el is különül az egységen belül (lásd Luhman 2006: 282-283). A beszélőtársak beszédükkel és megértésükkel tudásuk egy aktuális részét mozgósítják, cselekszenek, és érzelmeiket is a nyelvi tevékenység részévé teszik. A kommunikáció egyetemes közege az értelem. Az értelem az az elvárt médium, amelyben az információ (az, amiről szó van), annak nyelvi megkonstruálása referenciális jelenetekben és annak megértése elkülönül, majd összegződik. Az értelem közegében történik meg a megértés feltételeként a referenciális jelenet kiválasztása és elkülönítése más lehetséges ismeretek közül, valamint az információ közvetlen értelmi közegének (szelekciós horizontjának) a kijelölése vagy felismerése, hiszen az értelem közege adja meg a keretét annak az ismereti kontextusnak, amely a referenciális jelenet, végső soron a szöveg megalkotásakor és megértésekor előhívódik a beszélőtársakban. Az értelem mint általános közeg a kommunikáció során különböző megértési lehetőségeket nyit meg, és egyúttal a legvalószínűbbet ki is jelöli. E szelekciós folyamat nem csupán a referenciális jelenet (információ) körülhatárolására érvényes, hanem a beszélőtársak viszonyára is: a hallgatónak nem szükséges és nem is lehetséges a pillanatnyi beszélő összes motivációját és beállítottságát, belső értelmi és érzelmi horizontját megismerni vagy földeríteni az elmondott szöveg megértéséhez. 
A kommunikáció esemény, interakciós művelet (műveletsor), amely megértésben végződik, és egyúttal lehetőséget nyit a további kommunikációs műveletekre. A kommunikáció egyik fó jellemzője a folytonosság, az új kommunikációs műveletek végrehajtása, amelyek az előzőekre épülnek, pontosabban az előzőek eredményére, anélkül, hogy az előző kommunikációs művelet minden részlete a kezdetektől megismétlődne.

\section{A triadikus modell jelentősége az iskolában}

A jelen tanulmányban csak jelezni lehet, hogy az új NAT kommunikációs elvárásait csakis egy olyan kommunikációs modell iskolai alkalmazásával lehet elérni, amely a diákot, a beszélö embert cselekvő, a másik társ és a téma felé aktív figyelemmel irányuló, a közös kommunikációs tevékenységre kész személyként értelmezi, ezt a modellt érvényesíti az iskolában, és ezt tanítja. A NAT tervezete (NAT 2018: 43-44) a következőképpen foglalja össze a kommunikációs kompetenciák elvárhatóságát és ezek indokait: „Kommunikációs kompetenciák: A tanulás és tanítás állandó, a nevelési-oktatási szakasztól függő mélységü feladata az olvasott és hallás utáni szövegértés, a szóbeli és írásos szövegalkotás, továbbá a kommunikatív kontextust figyelembe vevő, tudatos nyelvhasználat fejlesztése. A kompetenciák különböző médiumokban (szóbeliség, hagyományos írott médiumok, digitális közeg) fejlesztendők. A kommunikációs kompetenciák fejlesztése segíti a munkavállalói innovációs és vállalkozói kompetenciák kialakítását (tájékozódás és részvétel a munka világában, rugalmas alkalmazkodás a munkaerőpiac kihívásaihoz).

Társadalmi részvétel és felelősségvállalás kompetenciái: Az irodalmi és nem irodalmi szövegek, média- és műalkotások megvitatása lehetővé teszik eltérő élethelyzetek és társadalmi perspektívák megismerését, az egyéni és közös értékek megvitatását, valamint a társadalmi és erkölcsi kérdések komplex megértésére irányuló igény felkeltését. A tanórákon az egyéni és csoportos munkaformák, kooperatív feladatok és projektek segítik az együttműködési készség és a felelősségvállalás kialakítását. Ugyanezen sajátosságok a személyes és társas kompetenciák fejlesztését is elősegítik.

Kreatív alkotás, önkifejezés és kulturális tudatosság kompetenciái: Az Anyanyelvi kommunikáció és irodalmi műveltség tanulási területén belüli fejlesztés fó feladata a helyi, a nemzeti, az európai és az egyetemes emberi kultúra hagyományai, alkotásai és szövegei iránti érdeklődés felkeltése, ezek egyre több szempontra kiterjedő megismerése, megértése és értelmezése. A tantárgy további célja a tanulók önreflexiós képességének kialakítása, tudatosítása és elmélyítése. Ennek eszközei lehetnek: az irodalmi és társművészeti alkotások élményszerü befogadása, vélemény megfogalmazása a felmerült témákról, irodalmi és nem irodalmi szövegek alkotása, valamint a tárgyalt témák kreatív feldolgozása (drámajátékok, színpadi és multimédiás prezentációk, egyéb kreatív projektek stb.).

A tanulás kompetenciái: Az anyanyelv és az irodalom ismerete kulcsfontosságú az egyes tantárgyak tanulásában, a tanulási eredményességben és a tanulási motiváció fejlesztésében." 
A NAT-tervezetben megjelölt (itt nem egészében idézett) kompetenciák kifejlesztése a diszkurzív, dinamikus kommunikációs modell révén módosíthatja a magyar kultúrának az ezredfordulón még mindig meglévő merev kommunikációs kultúráját. A posztkoloniális örökségként érvényét megtartó kijelentő kommunikációs kultúra helyébe így kerülhetne a beszélgető, eszmét cserélő, kérdező kommunikációs kultúra, amely nélkülözhetetlen a tudásalapú és innovációra törekvő európai társadalmakban.

\section{5. Összefoglalás}

A tanulmány (és az azt megelőző előadás) a kommunikációnak a hazai iskolarendszerben és tágabban a magyar kultúrában uralkodó statikus felfogását tárgyalta és bírálta, és helyette a triadikus funkcionális modellt javasolta. Kimutatta, hogy a statikusság hirdetői szerint a kommunikáció egyirányú, a beszélö a hallgatónak információt továbbít (,átad”), a folyamatban csak a beszélő cselekszik, a hallgató csupán beszélőváltás után lesz aktív, saját megszólalásával.

A tanulmány két magyar nyelvtani tankönyvcsalád köteteinek elemzését végzi el, rámutatva a strukturalista modell korlátaira. A statikussal szembeállítandó a dinamikus felfogás, amely a beszélőtársak aktív részvételét hangsúlyozza, az időben lezajló közös figyelemirányítást és a közös megértést, melynek során a hallgató is cselekszik, mert mentális erőfeszítést tesz a befogadás érdekében. A beszélő nem átadja az ismeretet (az nála is megmarad), hanem hallgatójának figyelmét arra irányítja, amivel ô is foglalkozik mentálisan, és ebben a közös fókuszálásban, a közös jelentésképzésben kapcsolódik össze két elme, két személy, önreflexíven is. Külön kiemelendő a dinamikus kommunikációs modellnek az iskolai személyiségfejlesztésben betöltendő pozitív, segítő szerepe, az, hogy a komplex megismerési folyamatokban a nyitott, diszkurzív kommunikációra való rávezetés kiemelt jelentőségű.

\section{Források}

Antalné Szabó Ágnes - Raátz Judit 2001. Magyar nyelv és kommunikáció. Tankönyv a 9-10. évfolyam számára. Nemzeti Tankönyvkiadó.

Baloghné Biró Mária - dr. Baranyai Katalin 2014. Magyar nyelv és kommunikáció. Tankönyv. 5. Oktatáskutató és Fejlesztő Intézet.

Dr. Hegedűs Attila - Téglásy Katalin 2014. Magyar nyelv és kommunikáció. Tankönyv. 9. Oktatáskutató és Fejlesztő Intézet.

\section{Irodalom}

Givón, Talmy 2002. Bio-linguistics. The Santa Barbara lectures. Amsterdam, Philadelphia: John Benjamins. https://doi.org/10.1075/z.113 
Jakobson, Roman 1969. Nyelvészet és poétika. In: Hang - jel-vers. Budapest: Gondolat Kiadó. 211-257.

Kemmer, Suzanne - Barlow, Michael 2000. Introduction: A usage-based conception of language. In: Barlow, Michael - Kemmer, Suzanne (eds.): Usage-Based Models of Language. Stanford, California: CSLI Publications. vii-xxviii.

Luhmann, Niklas 2006. Bevezetés a rendszerelméletbe. Budapest: Gondolat Kiadó.

NAT 2018. A Nemzeti alaptanterv tervezete.

www.oktatas2030.hu/wp-content/uploads/2018/08/a-nemzeti-alaptanterv-tervezete_ 2018.08.31.pdf (2020. 05.10.)

Sinha, Chris 2009. Language as a biocultural niche and social institution. In: Evans, Vyvyan - Pourcel, Stéphanie (eds.): New directions in cognitive linguistics. Amsterdam, Philadelphia: John Benjamins. 289-309.

Tátrai Szilárd 2011. Bevezetés a pragmatikába: funkcionális kognitiv megközelités. Budapest: Tinta Könyvkiadó.

Tátrai Szilárd 2017. Pragmatika. In: Tolcsvai Nagy Gábor (szerk.): Nyelvtan. Budapest: Osiris Kiadó. 899-1057.

Terestyéni Tamás 2006. Kommunikációelmélet. A testbeszédtöl az internetig. Budapest: Typotex Kiadó.

Tolcsvai Nagy Gábor 2016. Posztkoloniális korszak a magyar nyelv és nyelvközösség történetében. Magyar Nyelvör 140/4: 387-406.

Tomasello, Michael 2002. Gondolkodás és kultúra. Budapest: Osiris Kiadó. 